\title{
Corporate Governance and Accounting Conservatism: Moderating role of Audit Quality and Disclosure Quality
}

\author{
Muhammad Bilal Saeed ${ }^{1}$, Syed Kashif Saeed ${ }^{2}$
}

\begin{abstract}
This study investigates the moderating role of audit quality and disclosure quality on the association between corporate governance and accounting conservatism in three emerging economies of South Asia from 2009 to 2015. Complex corporate governance structures make expropriation of minority shareholders easier due to greater opportunities for controlling shareholders, thus allowing them to cloak their malpractices through accounting conservatism. We find that the level of accounting conservatism is positively associated with corporate governance stature, and higher audit quality and disclosure quality weakens this association. Our results suggest that users of financial statements should consider audit quality and disclosure quality for the evaluation of firms especially in environments where corporate governance is complex, ownership is concentrated and markets are still developing.
\end{abstract}

Keywords: Accounting Conservatism, Audit Quality, Corporate Governance, Disclosure Quality.

JEL Classification: G30, G38, G39

\section{Introduction}

The emergence of corporate accounting scandals and transnational firms have increased the academic interest in financial reporting issues. Jensen and Meckling (1976) describe shareholders' rights on the basis of complex set of contracting relationships. Many empirical studies corroborate that better corporate governance can mitigate agency problems and associated costs through its internal and external mechanisms (e.g. Subramaniam, 2006). Ball and Shivakumar (2005), Ahmed and Duellman (2007) and Garc1'a Lara et al. (2009) have empirically proved the existence of association between corporate governance and accounting conservatism. These studies, establishing a positive link between corporate governance and accounting conservatism,

1 PhD Scholar, Capital University of Science and Technology, Islamabad. Email: mbfsaeed@gmail.com 2 Pakistan Institute of Engineering $\mathcal{E}$ Applied Sciences, Islamabad Email: syedksaeed@gmail.com

\begin{tabular}{lll}
\multicolumn{2}{l}{ ARTICLE HISTORY } \\
8 Feb, 18 & Submission Received & 22 Feb, 18 First Review \\
\hline 23 Mar, 18 & Revised Version Received & 10 May, 18 Second Review \\
\hline 14 May, 18 & Revised Version Received & 26 May, 18 Accepted
\end{tabular}


built their argument on the significance of conservatism in contracting. They argue that when shareholders demand more information, firms install more mechanisms to reduce information asymmetry between the managers and stakeholders that support conservatism. This reduces shareholders' trust in financial reports, which leads to decrease in market efficiency. The link between corporate governance and accounting conservatism becomes particularly significant in the context of emerging economies, where protection of shareholders' and creditors' rights is still an issue (Sarkar et al., 2008). Improving audit quality and disclosure quality can be the key to enhancing financial reporting quality in an emerging market setting.

Accounting conservatism is defined as the recognition of revenues only when they are assured of being received whereas the recognition of expenses even when there is an uncertainty of outcome involved (Bliss, 1924). Basu (1997) defines conservatism as the propensity to demand excessive investigation for identification of good news rather than bad news while reporting earnings. Givoly and Hayn (2000) consider conservatism as an accounting tool that leads to faster recognition of expenses and slower recognition of revenues. Conservatism is simply defined as the asymmetric timeliness in recognizing losses versus gains (Watts, 2003). Conservatism can hence be defined in a manner that if there is a lack of conviction in any transaction one should identify and record all possible losses but should not identify and record all possible revenues. Corporate governance is a term that stands for the structural as well as relational stature of the corporate entity. This structural and relational framework sets the direction of the firm and is also responsible for its performance. According to Blair (1995) the governance of a firm is a tricky task as it involves the collection of cultural, institutional and legal frameworks positioned in such a way so as to direct the firm or the corporate entity. This set also determines the right to control or manage the organization, including the power to make strategic decisions.

The stature of governance in a firm determines the demand for conservatism. More effective the stature of governance leads to a greater demand for conservatism. This relationship is in line with the theoretical justifications set forth to link corporate governance with accounting conservatism. The agency theory perspective considers conservatism as a tool that can be employed to reduce agency conflict. Thus the managers are motivated by structural as well as relational mechanism within the firms to demand conservatism. The positive accounting theory (Watts \& Zimmerman, 1986) perspective considers conservatism as an effective accounting tool that can be employed to gain the benefits in case of contracts. Thus the managers while engaging into contracts are persuaded by governance frameworks installed within the organizations to demand more conservatism because of its significance in accounting.

The existing studies that strive to address the connection between accounting 
conservatism and corporate governance have certain limitations. First these studies are limited to developed economies only. For example, Elshandidy and Hassanein (2014) attempt to analyze the impact of director's independence on accounting conservatism in FTSE firms. Shuto and Takada (2010) and Kung, Cheng, and James (2010) investigate the role of ownership structure on accounting conservatism in Japanese and Chinese listed firms respectively. Ahmed and Duellman (2007) and Beekes, Pope, and Young (2004) examine the role played by characteristics of board in persuading the firms to follow conservative accounting in US and UK listed firms respectively. The difference between developed and developing economies in the context of institutional framework, inclination and awareness about corporate governance and development of corporate governance infrastructure prompt the need for examination of understudy relationship in emerging economies as well. Second, the existing studies are also limited to follow an indirect approach based on Basu's model (1997), and modified by Roychowdhury and Watts (2007) and Ahmed and Duellman (2007). Under this approach accounting conservatism is not measured and examined as separate dependent variable rather interaction terms are created with considered independent variables and, the change in earnings and accruals of the firms because of changes in these interaction terms is examined to analyze conservatism. This limitation in estimation procedure also paves the way for this examination. Third limitation is related to the examination of a few corporate governance mechanisms only. The exploration of new governance variables that could alter the connection between corporate governance and accounting conservatism also paves the way for this study. Moreover, the existing studies involve composite measures for corporate governance and accounting conservatism. The limitation associated with these measures include biased assignment of weights for the development of composite measures and inclusion of inadequate measures from whom these composites are being constructed. Last but not the least, the role of disclosure quality and audit quality in moderating the relationship between corporate governance and accounting conservatism has never been explored before. Existing studies are limited to exploring the relationship only and do not involve examination of any moderator even though the theoretical justification exist for its investigation. This study contributes to the existing literature by addressing the gaps mentioned above. Considering a sample of 300 firms from three emerging economies of South Asia, this study empirically investigates the role of corporate governance - board composition, CEO characteristics, and ownership structure - in accounting conservatism in these economies and the moderating impact of audit quality as well as disclosure quality on this relationship.

This study is different from previous studies in several ways. First, we investigate the effect of corporate governance via direct approach. Second, we focus on development of a composite measure of corporate governance where weights are assigned by 
employing principal component analysis on explored governance variables. Third, we identify two corporate governance aspects whose effect on accounting conservatism is not yet explored especially in emerging markets. These two aspects are CEO turnover and gender diversity on board. A new CEO may or may not pursue the accounting practices that are installed in firms. Moreover, the presence of women on board, can also have an impact on the extent of conservatism. Hence, we focus on including these mechanisms into our composite measure. Fourth, following Donovan, Frankel, and Martin (2015), we estimate five measures of accounting conservatism. Two of these measures are earnings based, two are accruals based and one is skewness based. We develop a composite measure of firm's conservatism from these measures where weights are assigned by employing principal component analysis. Fifth, we explore the moderating role of audit quality and disclosure quality on the relationship between corporate governance and accounting conservatism for three emerging economies of South Asia.

In Bangladesh, India and Pakistan shareholder's protection is weak and ownership is concentrated in families. Even though, the stature of corporate governance has improved because of implementation of corporate governance codes, the distinction of ownership and control is still vague. For these economies, the empirical evidence can have significant implications. For the managers and investors, the employment of complex corporate governance mechanisms can enhance the level of conservatism employed by firms. The regulators can take into consideration the aspects of audit quality while developing regulations for firms in these countries. For the firms that are working in those countries where ownership is concentrated and the line between ownership and control is very thin, the existing study can offer significant implications.

This study is organized into five sections. Section 2 presents reviews of empirical and theoretical literature on the association between corporate governance and accounting conservatism. Section 3 presents details of the sample, variable specification and estimation procedures. Section 4 presents results and discussion, followed by the Section 5 of conclusion, recommendations and future research directions.

\section{Literature Review and Hypothesis Development}

\subsection{Corporate governance, accounting conservatism and audit quality}

Beekes et al. (2004) demonstrate that board composition and managerial ownership are significantly related to the level of conservatism. Ahmed and Duellman (2007) using data of companies listed in US investiagte how independence of board and ownership structure affect conservatism. They find that there exist a positive affect of these measures on accounting conservatism. Garc1'a Lara et al. (2007) using 
composite measure of firm's governance, analyze the relationship between board composition and accounitng conservatism in Spanish firms. They document a positive accosaition between the board structures and conservatism. Krishnan and Visvanathan (2008) show the separation of CEO and chairman of the board is associated with more conservatism. Young et al. (2008) empirically prove that ownership structure is negatively related to conservatism. Kung et al. (2010) examine listed companies in China and find that, firms with more concentrated owners deploy less conservatism in reporting accounting information. The reason is that the owners can solve conflicts of interest personally hence reducing agency conflict and decreasing conservatism. Rosilda (2009) also empirically proves the positive role of independent audit committee in following conservative accounting practices. Suleiman and Anifowose (2014) using the data from Nigerian firms document that board composition and ownership structure have an impact on accoutning conservatism. Karami, Hoseini and Hasani (2010) using the data of firms listed in Tehran stock market document that all major mechnaisms of corporate governance have influence on accounting conservatism. In a nut shell, a large number of researchers have empirically proved that there exists a positive association between corporate governance and accounting conservatism. Hence, paving the way for development of our first hypothesis as follows:

$\mathrm{H}_{1}$ : There exists a relationship between corporate governance of firm and accounting conservatism.

Basu, Hwang, and Jan (2001) find that fourth quarter earnings are more conservative than earlier quarters' earnings and the difference in conservatism between the fourth and earlier quarters is higher in periods of high auditor liability. This result is consistent with auditors' views in adopting conservatism to reduce litigation costs. It is assumed that the assurance is more credible if it comes from big accounting firms (audit quality is proxied by existence of big four auditor in existing studies) because they need to maintain their reputation, are subject to greater public scrutiny and have high litigation risks (Chung, Firth \& Kim, 2003). Previous studies show that large auditing firms are more effective in curbing opportunistic earnings management and thus reducing the level of accounting conservatism employed by the firms. Basu, Hwang and Jan (2002) and Chung, Firth and Kim (2003) find that earnings of firms which employ a big four auditor reflect bad news earlier than good news (Chung, Firth \& Kim, 2003). They find that the big four auditors are more effective than the non-big four auditors at monitoring income increasing accruals choices but are less effective than the non-big four auditors at monitoring income decreasing accruals choices. This result suggests that the presence of big four auditors can improve the audit quality that in turn reduces the level of conservative accounting procedures even in the existence of complex corporate governance structures. Francis et al. 
(1999) and later on Krishnan (2003) also argue that the audit quality can play a significant role in improving the conservative reporting of earnings. It is being reported by many studies that the quality of audit reduces the false management of earnings thus mitigating conservatism (Lennox, 2005; Francis \& Wang, 2008; Ching et al., 2015; Persakis \& Iatridis, 2016). It is interesting to note that the literature is very thin while addressing the moderating role of audit quality on the relationship between corporate governance and accounting conservatism. One of the reasons may be that most of the researchers are concerned over the role of big four auditor as the determinant of accounting conservatism only and overlooked its ability to moderate the governance-conservatism relationship. Still the argument cannot be smoked away that in the countries like Pakistan the corporate governance mechanisms have developed over time and this has given a rather privileged position to the managers who now could implement more conservative practices in order to fabricate their misconduct. Under these circumstances, the improved quality of the audit can necessarily weaken this relationship. The following hypothesis can hence be formulated:

$\mathrm{H}_{2}$ : High audit quality moderates the association between corporate governance of firms and accounting conservatism.

\subsection{Corporate governance,accounting conservatism and disclosure quality}

Brown and Hillegeist (2007) examine the relationship between disclosure quality and accounting conservatism. They report a negative relationship between conditional conservatism and disclosure quality. They argue that if the disclosure quality is better, the information asymmetry will be reduced. Later in 2008, Lafond and Watts argue that it is the information asymmetry between notified and non-notified investors that lead to conservatism. They empirically prove that if quality of disclosed information is improved, more and more investors will switch over to the notified investors side thus reducing the level of conservatism. This improvement in disclosure quality is tied to the governance stature of firms. Artiach and Clarkson (2012) study the relationship between accounting conservatism and cost of equity in two sub samples. These sub samples include firms with high disclosure quality and firms with low disclosure quality. They find that there exist a negative relationship between the level of conservatism and cost of equity in case of firms having high disclosure quality. Noravesh and Hosseini (2008) investigate the relationship between disclosure quality and earnings management. They show that there is a significant but negative relationship between disclosure quality and earnings management. Following them, Rahimian and Ebrahimi (2013) examine the relationship between disclosure quality, earnings management, conditional and unconditional conservatism. They report a positive significant re- 
lationship between disclosure quality and conditional conservatism and a negative significant relationship between disclosure quality and unconditional conservatism. In the countries like Pakistan and Bangladesh, the ownership is concentrated and the line between ownership and control is thin. The managerial end in order to save their skin employ conservatism. The level of conservatism employed can be reduce by improving disclosure quality. The following hypothesis can hence be formulated:

$\mathrm{H}_{3}$ : High disclosure quality moderates the association between corporate governance of firms and accounting conservatism.

\section{Research Design}

\subsection{Sam ple selection and data}

Three samples each comprising of 100 non-financial listed firms is taken from the firms listed in Bangladesh, India and Pakistan. The reason of collecting data from non-financial sector is that there is a significant difference between the structures and accounting practices of financial and non-financial companies (Wei, 2007). Selection of firms in the sample is based on high market capitalization and data availability for the given period. Secondary data is employed for the purpose of estimation. Most of the data is extracted from the annual reports of individual firms. However some missing data is collected from company's websites and other published reports. The classification of non-financial firms in the samples is presented in appendix 1.

\subsection{Estimation of accounting conservatism}

To measure accounting conservatism (AC), a composite measure is used. Following the argument set forth by Donovan, Frankel and Martin (2015) that there is a lack of consensus in the empirical literature especially with reference to a single measure of conditional conservatism, this study first estimates five conservatism measures and then develops a composite measure to capture conditional conservatism. Different measures of conservatism are estimated as follows:

The first measure is sensitivity of earnings to bad news relative to sensitivity of earnings to good news $\left(\mathrm{ACsoe}=\left(\beta_{2}+\beta_{3}\right) / \beta_{2}\right)$ and is adopted from Zhang (2008) who has used the Basu's (1997) discussion to develop it. A firm specific regression over the rolling ten-year period is employed:

$$
\mathrm{EPS}_{\mathrm{i}, \mathrm{t}} / \mathrm{P}_{\mathrm{i}, \mathrm{t}-1}=\beta_{0}+\beta_{1} \mathrm{NEG}_{\mathrm{i}, \mathrm{t}}+\beta_{2} \mathrm{RET}_{\mathrm{i}, \mathrm{t}}+\beta_{3} \mathrm{NEG}_{\mathrm{i}, \mathrm{t}}{ }^{*} \mathrm{RET}_{\mathrm{i}, \mathrm{t}}+\varepsilon_{\mathrm{i}, \mathrm{t}}
$$

where EPS $_{\mathrm{i}, \mathrm{t}} / \mathrm{P}_{\mathrm{i}, \mathrm{t}-\mathrm{1}}$ is the earnings per share for firm $\mathrm{i}$ in year $\mathrm{t}$ deflated by the beginning period stock price, $\mathrm{NEG}_{\mathrm{i}, \mathrm{t}}$ is a dummy variable that is equal to 1 if $\mathrm{RET}_{\mathrm{i}, \mathrm{t}}$ 
is negative and 0 otherwise. RET ${ }_{i, t}$ is a 12 month return of firm i ending 3 months after the end of fiscal year. $\beta_{2}$ represents sensitivity of earnings of a firm to good news whereas the sum of two coefficients i.e. $\beta_{2}$ and $\beta_{3}$ shows sensitivity of earnings of a firm to bad news. The higher the ACsoe, the more is the conservatism.

The second measure is coefficient of the interaction term D $\Delta$ EPS $_{i, t-1}{ }^{*} \Delta \mathrm{EPS}_{\mathrm{i}, \mathrm{t}-1}$ (ACcie) and is also based on the Basu's (1997) argument. Again a firm specific regression over a rolling ten-year period is estimated:

$$
\Delta \mathrm{EPS}_{\mathrm{i}, \mathrm{t}}=\beta_{0}+\beta_{1} \mathrm{D} \Delta \mathrm{EPS}_{\mathrm{i}, \mathrm{t}-1}+\beta_{2} \Delta \mathrm{EPS}_{\mathrm{i}, \mathrm{t}-1}+\beta_{3} \mathrm{D} \Delta \mathrm{EPS}_{\mathrm{i}, \mathrm{t}-1}{ }^{*} \Delta \mathrm{EPS}_{\mathrm{i}, \mathrm{t}-1}+\varepsilon_{\mathrm{i}, \mathrm{t}}
$$

where $\triangle \mathrm{EPS}_{\mathrm{i}, \mathrm{t}}$ is change in earnings per share for firm $\mathrm{i}$ in year $\mathrm{t}$ deflated by average assets. $\triangle \mathrm{EPS}_{\mathrm{i}, \mathrm{t}-1}$ is change in earnings per share for firm $\mathrm{i}$ in year $\mathrm{t}-1$ deflated by average assets. D $\Delta \mathrm{EPS}_{\mathrm{i}, \mathrm{t}-1}$ is a dummy variable that is equal to 1 if $\Delta \mathrm{EPS}_{\mathrm{i}, \mathrm{t}-1}$ is negative (less than 0 ) and 0 otherwise. $\beta_{3}$ represents the extent to which economic losses are recognized timelier than economic gains hence captures conservatism. If this estimate is high the more is the conservatism employed by the firm.

The third measure of accounting conservatism as represented by accruals (ACacc) is estimated as follows:

Accruals $=($ Income + Depreciation expense - Operating cash flows $) \div$ Total Assets

$\mathrm{ACacc}=($ Accruals averaged over 3years $) \times(-1)$

The fourth measure of accounting conservatism is the coefficient of the interaction term $\mathrm{DCFOi}, \mathrm{t}^{*} \mathrm{CFO} \mathrm{i}, \mathrm{t}$ (ACcic) and is estimated via a firm specific regression over a rolling ten-year period as follows:

$$
\text { Accruals }_{\mathrm{i}, \mathrm{t}}=\beta_{0}+\beta_{1} \mathrm{DCFO}_{\mathrm{i}, \mathrm{t}}+\beta_{2} \mathrm{CFO}_{\mathrm{i}, \mathrm{t}}+\beta_{3} \mathrm{DCFO}_{\mathrm{i}, \mathrm{t}}{ }^{*} \mathrm{CFO}_{\mathrm{i}, \mathrm{t}}+\mu_{\mathrm{i}, \mathrm{t}}
$$

where, Accruals $\mathrm{s}_{\mathrm{i}, \mathrm{t}}$ are the accruals for firm i in year $\mathrm{t}, \mathrm{CFO}_{\mathrm{i}, \mathrm{t}}$ is cash flow from operations and $\mathrm{DCFO}_{\mathrm{i}, \mathrm{t}}$ is a dummy variable that takes the value of 1 if $\mathrm{CFO}_{\mathrm{i}, \mathrm{t}}$ is negative $(<0)$ and 0 otherwise. This measure is calculated by following the argument of Ball and Shivakumar (2005) in which $\beta_{3}$ represents extent to which accruals generated in a firm during a certain time period are timely in capturing cash flows. According to them, conservatism simply means earlier identification of positive cash flows as compared to negative cash flows. Negative cash flows are recognized earlier than positive cash flows hence capture conservatism. Higher the measure, the more is the conservatism employed by the firm.

The fifth measure is skewness of earnings deflated by skewness of cash flows (ACskew). It captures the difference between the skewness of operating cash flows 
and earnings, following Beatty et al. (2008). At least three annual observations are required to compute skewness. When bad news is recognized in earnings more quickly than good news, earnings are negatively skewed relative to the cash flows of the firm. Greater the level of skewness the more is the conservatism of the firm.

The composite measure is developed by calculating weighted average of all measures as presented below. The weights are being assigned through principal component analysis and presented in table 1 . A high value depicts more conservatism.

$$
\mathrm{AC}=\sum\left[\mathrm{w}_{1} \mathrm{ACsoe}+\mathrm{w}_{2} \mathrm{ACcie}+\mathrm{w}_{3} \mathrm{ACacc}+\mathrm{w}_{4} \mathrm{ACcic}+\mathrm{w}_{5} \mathrm{ACskew}\right]
$$

Table 1: Weights Assigned to Individual Conservatism Measures*

\begin{tabular}{|c|c|c|c|}
\hline & Bangladesh & India & Pakistan \\
\hline Variables & Factor Loadings/Weights & Factor Loadings/Weights & Factor Loadings/Weights \\
\hline ACACC & 0.498 & 0.520 & 0.698 \\
\hline ACCIC & 0.602 & -0.583 & -0.150 \\
\hline ACCIE & 0.490 & -0.075 & 0.042 \\
\hline ACSKEW & 0.314 & 0.326 & 0.698 \\
\hline ACSOE & 0.220 & 0.520 & 0.006 \\
\hline
\end{tabular}

*Values rounded to three decimal places

\subsection{Measurement of com posite score of firm governance (CSFG)}

Nine aspects of corporate governance are considered for the development of a composite score for firm governance. Board size (BS) is captured as the number of members on the board of the firm. The board independence (BI) is captured by calculating a ratio of independent directors to total directors on the board. The board activity (BA) is calculated by the ratio of number of meetings attended by at least 80 percent of board members to total number of meetings held. The gender diversity (GDB) is calculated by using a ratio of number of female members on the board to total board members. CEO turnover (CEOT) is represented by a dummy variable that takes the value of 1 if the turnover takes place and 0 otherwise. A dummy variable is used to capture CEO Duality (CEOD). This dummy takes the value of, " 1 " if CEO and Chairman are same and, "O" otherwise. The institutional ownership (INSO) is the ratio of number of shares held by the institutions to total number of shares of a firm. The managerial ownership (MANO) is captured by using a ratio. This ratio is estimated by dividing the number of shares held by directors on the board to total number of firm's shares. The audit committee independence (ACI) is captured by calculating a ratio of number of independent directors on the audit committee to total number of audit committee members. Following Latif, Bhatti and Raheman 
(2017), a composite measure is developed by calculating the weighted average of all the measures as presented below. The weights are being assigned through principal component analysis and presented in table 2. Higher the value of this measure, higher is the level of governance of a firm.

$\mathrm{CSFG}=\Sigma\left[\mathrm{w}_{1} \mathrm{ACI}+\mathrm{w}_{2} \mathrm{BA}+\mathrm{w}_{3} \mathrm{BI}+\mathrm{w}_{4} \mathrm{BS}+\mathrm{w}_{5} \mathrm{CEOD}+\mathrm{w}_{6} \mathrm{CEOT}+\mathrm{w}_{7} \mathrm{GDB}+\right.$
$\left.\mathrm{w}_{8} \mathrm{INSTO}+\mathrm{w}_{9} \mathrm{MANO}\right]$

Table 2: Weights Assigned to Individual Governance Measures/Mechanisms*

\begin{tabular}{|c|c|c|c|}
\hline & Bangladesh & India & Pakistan \\
\hline Variables & Factor Loadings/Weights & Factor Loadings/Weights & Factor Loadings/Weights \\
\hline ACI & -0.264 & -0.241 & -0.184 \\
\hline BA & 0.096 & 0.086 & 0.123 \\
\hline BI & 0.287 & 0.435 & 0.551 \\
\hline BS & -0.188 & 0.217 & 0.391 \\
\hline CEOD & 0.414 & 0.417 & -0.571 \\
\hline CEOT & -0.159 & -0.117 & -0.016 \\
\hline GDB & 0.535 & 0.597 & 0.129 \\
\hline INSTO & 0.161 & 0.175 & 0.370 \\
\hline MANO & 0.540 & 0.166 & 0.117 \\
\hline
\end{tabular}

* Values rounded to three decimal places

\subsection{Measurement of audit quality}

Following Rajgopal, Srinivasan and Zheng (2015), we use a dummy variable to measure audit quality. This dummy variable (BIG4D) that takes the value, " 1 " if the firm is audited by a big 4 auditor, "O" otherwise.

\subsection{Measurement of disclosure quality}

Following Cheung, Jiang and Tan (2010), we develop a disclosure index and use it as a proxy for disclosure quality. The maximum score that a company can obtain on this index is 1 . The score estimation is divided into five aspects which are combined to make an aggregate score for each company. These aspects are presented in appendix 2 .

\subsection{Control Variables}

Four firm specific control variables are employed in this study. The firm size (FS) is calculated by taking natural logarithm of total assets. The leverage (LEV) is 
calculated by dividing total debt by total equity of the firm. The profitability (ROA) is measured by calculating Return on Assets of the firm. Market to book value (MTB) is calculated by dividing market value of firm by book value of firm.

\subsection{Em pirical model}

Following Muttakin, Khan and Mihret (2017), we use following equations (1A), $(2 \mathrm{~A})$ and $(3 \mathrm{~A})$ to test $\mathrm{H}_{1}$. The equations (1B) and (3B) are used to test $\mathrm{H}_{2}$ and equations (2B) and (3B) are used to test $\mathrm{H}_{3}$. This study first examines the role of both the moderators in isolation and afterwards their combined effect, hence using both the Hayes models.

$$
\begin{aligned}
\mathrm{AC}_{i, t} & =\beta_{0}+\beta_{1} \mathrm{CSFG}_{i, t}+\beta_{2} \mathrm{AQ}_{i, t}+\beta_{3} \mathrm{FS}_{i, t}+\beta_{4} \mathrm{LEV}_{i, t}+\beta_{5} \mathrm{PROF}_{i, t}+\beta_{6} \mathrm{MTB}_{i, t}+\mu_{t}(1 \mathrm{~A}) \\
\mathrm{AC}_{i, t} & =\beta_{0}+\beta_{1} \mathrm{CSFG}_{i, t}+\beta_{2} \mathrm{AQ}_{i, t}+\beta_{3} \mathrm{CSFG}^{*} \mathrm{AQ}_{i, t}+\beta_{4} \mathrm{FS}_{i, t}+\beta_{7} \mathrm{LEV}_{i, t}+\beta_{5} \mathrm{PROF}_{i, t}+ \\
\beta_{7} \mathrm{MTB}_{i, t}+ & \mu_{t}
\end{aligned}
$$

$$
\begin{aligned}
\mathrm{AC}_{i, t} & =\beta_{0}+\beta_{1} \mathrm{CSFG}_{i, t}+\beta_{2} \mathrm{DQ}_{i, t}+\beta_{3} \mathrm{FS}_{i, t}+\beta_{4} \mathrm{LEV}_{i, t}+\beta_{5} \mathrm{PROF}_{i, t}+\beta_{6} \mathrm{MTB}_{i, t}+\mu_{t}(2 \mathrm{~A}) \\
\mathrm{AC}_{i, t} & =\beta_{0}+\beta_{1} \mathrm{CSFG}_{i, t}+\beta_{2} \mathrm{DQ}_{i, t}+\beta_{3} \mathrm{CSFG}^{*} \mathrm{DQ}_{i, t}+\beta_{4} \mathrm{FS}_{i, t}+\beta_{7} \mathrm{LEV}_{i, t}+\beta_{5} \mathrm{PROF}_{i, t}+ \\
\beta_{7} \mathrm{MTB}_{i, t}+ & \mu_{t}
\end{aligned}
$$

$$
\mathrm{AC}_{i, t}=\beta_{0}+\beta_{1} \mathrm{CSFG}_{i, t}+\beta_{2} \mathrm{AQ}_{i, t}+\beta_{3} \mathrm{DQ}_{i, t}+\beta_{4} \mathrm{FS}_{i, t}+\beta_{5} \mathrm{LEV}_{i, t}+\beta_{6} \mathrm{PROF}_{i, t}+\beta_{7} \mathrm{MTB}_{i, t}
$$
$+\mu_{t}(3 A)$

$$
\begin{aligned}
\mathrm{AC}_{i, t} & =\beta_{0}+\beta_{1} \mathrm{CSFG}_{i, t}+\beta_{2} \mathrm{AQ}_{i, t}+\beta_{3} \mathrm{CSFG}^{*} \mathrm{AQ}_{i, t}+\beta_{4} \mathrm{DQ}_{i, t}++\beta_{5} \mathrm{CSFG}^{*} \mathrm{DQ}_{i, t}+ \\
\beta_{6} \mathrm{FS}_{i, t}+\beta_{7} \mathrm{LEV}_{i, t}+\beta_{8} \mathrm{PROF}_{i, t}+\beta_{9} \mathrm{MTB}_{i, t}+\mu_{t} & \text { (3B) }
\end{aligned}
$$

In above three equations (1A), $(2 \mathrm{~A})$ and $(3 \mathrm{~A})$, the key variable of interest is the composite score of firm governance. We expect a positive significant coefficient of $\beta_{1}$ to support our first hypothesis. In equations (1B) and (3B), the key variables of interest are the interaction term between the composite score of firm governance and audit quality. We expect a negative and significant coefficient of $\beta_{3}$ in both equations (1B) and (3B). In equations (2B) and (3B), the key variables of interest are the interaction term between the composite score of firm governance and disclosure quality. We expect a negative and significant coefficient of $\beta_{3}$ in equations (2B) and of $\beta_{5}$ in equation (3B). Ahmed, Duellman and Watt (2007), Ming and Gee (2008) and Youns (2012) are a few researchers who have employed Panel data methodology for the purpose of analysis. The use of this methodology offers better information as if includes multiple observations on cross sectional units, thus estimating reliable estimates. The equations $1(A \& B), 2(A \& B)$ and $3(A \& B)$ are estimated separately for each of the three economies. The reason is that these three economies differ in institutional framework, inclination and awareness about corporate governance, de- 
velopment of corporate governance infrastructure and framework, financial reporting practices as well as accounting standards.

\section{Analysis and results}

Table 3 presents the descriptive statistics of all the variables.

It is evident from this table that the mean AC for Bangladesh, India and Pakistan is $-0.37,2.90$ and 0.12 respectively. These values are distinct from those reported by Ahmed and Duellam (2007), Krishnan and Visvanathan (2008), Yunos (2011) and

\begin{tabular}{|c|c|c|c|c|c|c|c|c|c|}
\hline \multirow{4}{*}{ 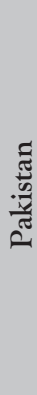 } & 离 & $\stackrel{\vec{T}}{0}$ & $\stackrel{\infty}{+}$ & $\begin{array}{l}\text { oे } \\
\text { oे }\end{array}$ & \begin{tabular}{l}
$\infty$ \\
\hdashline \\
$\vdots$
\end{tabular} & $\tilde{\tilde{\tau}}$ & $\stackrel{0}{\stackrel{\sim}{0}}$ & $\begin{array}{l}\infty \\
0 \\
0\end{array}$ & 守. \\
\hline & $\stackrel{g}{\Sigma}$ & $\stackrel{n}{?}$ & $\stackrel{8}{8}$ & ले. & $\underset{\sim}{\stackrel{ }{\sim}}$ & $\begin{array}{l}\tilde{\sigma} \\
\stackrel{0}{0}\end{array}$ & $\vec{\square}$ & in & $\begin{array}{l}\tilde{o} \\
\dot{0}\end{array}$ \\
\hline & 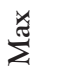 & $\stackrel{\infty}{\stackrel{\infty}{\rightarrow}}$ & ن. & $\begin{array}{c}\tilde{0} \\
0 \\
0\end{array}$ & $\begin{array}{l}\widetilde{\sigma} \\
\dot{0}\end{array}$ & $\stackrel{\sim}{\stackrel{+}{ \pm}}$ & ฉ. & $\vec{\sim}$ & $\begin{array}{l}\stackrel{\circ}{2} \\
\sim \\
\sim\end{array}$ \\
\hline & 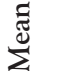 & $\stackrel{7}{\longrightarrow}$ & $\ddot{0}$ & $\begin{array}{l}\tilde{\sigma} \\
\dot{0}\end{array}$ & $\begin{array}{l}\dot{8} \\
\dot{m}\end{array}$ & 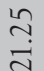 & $\begin{array}{l}\overrightarrow{+} \\
\dot{0}\end{array}$ & ๐̆ & $\begin{array}{l}+ \\
\infty \\
0\end{array}$ \\
\hline \multirow{4}{*}{$\stackrel{\Xi}{\stackrel{\Xi}{\Xi}}$} & 岕 & $\vec{\sim}$ & $\stackrel{q}{+}$ & $\begin{array}{l}0 \\
0 \\
0\end{array}$ & $\tilde{\tilde{0}}$ & ธิ & $\overrightarrow{\tilde{o}}$ & $\stackrel{\circ}{\circ}$ & $\underset{\dot{m}}{\dot{\sigma}}$ \\
\hline & $\Xi$ & $\begin{array}{l}\infty \\
\stackrel{0}{0} \\
\stackrel{1}{1}\end{array}$ & 8 & $\frac{0}{0}$ & $\underset{\sim}{\stackrel{\sim}{\leftrightarrows}}$ & 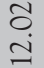 & 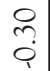 & กิ & $\begin{array}{l}\stackrel{0}{2} \\
i p\end{array}$ \\
\hline & 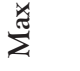 & $\stackrel{0}{\circ}$ & $\stackrel{8}{8}$ & $\begin{array}{l}0 \\
\stackrel{0}{0} \\
0\end{array}$ & $\begin{array}{l}\tilde{O} \\
\dot{r}\end{array}$ & 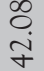 & $\tilde{O}$ & $\tilde{n}$ & $\begin{array}{l}\hat{b} \\
\vec{m}\end{array}$ \\
\hline & 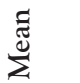 & 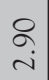 & ถે. & $\stackrel{n}{\tilde{n}}$ & $\begin{array}{l}\stackrel{n}{\sim} \\
\sim\end{array}$ & $\begin{array}{l}\text { ⿵ె } \\
\ddot{\sim}\end{array}$ & $\underset{+}{+}$ & $\stackrel{0}{3}$ & $\overrightarrow{\tilde{n}}$ \\
\hline \multirow{5}{*}{ 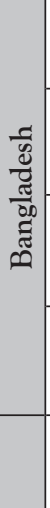 } & 离 & $\begin{array}{l}\vec{\sigma} \\
0\end{array}$ & 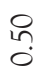 & $\stackrel{\Xi}{ \pm}$ & $\begin{array}{l}\vec{\bullet} \\
\dot{0}\end{array}$ & $\stackrel{+}{\rightarrow}$ & $\begin{array}{l}\vec{\infty} \\
\dot{0}\end{array}$ & $\stackrel{\sigma}{\circ}$ & $\stackrel{q}{\dot{q}}$ \\
\hline & $\Xi$ & $\stackrel{8}{\circ}$ & $\stackrel{8}{\circ}$ & $\vec{\circ}$ & 8 & $\begin{array}{l}\tilde{0} \\
\infty \\
\infty\end{array}$ & $\tilde{0}$ & $\begin{array}{l}\text { Oे } \\
\text { Q }\end{array}$ & $\hat{0}$ \\
\hline & $\sum_{\Sigma}^{\stackrel{\Xi}{\Sigma}}$ & $\begin{array}{l}\tilde{\sigma} \\
\dot{\sigma}\end{array}$ & $\stackrel{8}{8}$ & $\begin{array}{l}\hat{b} \\
\dot{0}\end{array}$ & $\begin{array}{l}\tilde{\sigma} \\
\stackrel{+}{*}\end{array}$ & ๗ँ. & $\stackrel{n}{n}$ & $\stackrel{n}{0}$ & $\begin{array}{l}\stackrel{0}{2} \\
\end{array}$ \\
\hline & $\sum^{\varpi}$ & $\tilde{n}$ & $\stackrel{+}{+}$ & 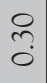 & $\stackrel{0}{ت}$ & $\tilde{\sim}$ & $\underset{\mathrm{O}}{\mathrm{O}}$ & ठّم & $\begin{array}{l}\overrightarrow{+} \\
\stackrel{0}{0}\end{array}$ \\
\hline & & $\underset{\varangle}{U}$ & $\stackrel{a}{\&}$ & $a$ & 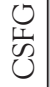 & 足 & 羙 & $\begin{array}{l}\text { W } \\
\text { 㐘 }\end{array}$ & $\stackrel{\theta}{\Sigma}$ \\
\hline
\end{tabular}


Ren (2014). Ahmed and Dellman (2007) and Krishnan and Visvanathan (2008) report a mean value of 0.010 for US market where as Yunos (2011) and Ren (2014) present the mean values of accrual based conservatism measures of -0.006 and -0.014 for Malaysian and Chinese markets respectively. It is inferred that the firms listed in India and Pakistan employ more conservatism whereas the firms listed in Bangladesh employ less conservatism as compared to the firms listed in US, Malaysia and China. The mean values of composite score of firm governance is 1.10, 2.15 and 3.60 for non-financial firms listed in Bangladesh, India and Pakistan respectively. This number is in line with many studies conducted in developing markets for example by Rahman and Ali (2006) and Haniffa and Hudaib (2006). About 44.3\%, 59\% and 63.1\% of the sample from Bangladesh, India and Pakistan respectively is found to be audited by big four auditors. This number is more than that is reported by Yatim et al. (2006), Yunos (2011) and Ren (2014) for Malaysian and Chinese firms. The mean of the disclosure quality for Bangladesh is 0.30 , for India is 0.35 and for Pakistan is 0.62 .

Based on the Hausman specification test, the following table 4 shows the results of firm fixed effect model for equation $1 \mathrm{~A}$

The results of all three countries in our sample show that our key variable i.e. composite score of firm governance is significant with signs relevant to that was

Table 4: Results of Equation 1(A)

\begin{tabular}{|c|c|c|c|c|c|c|}
\hline & \multicolumn{2}{|c|}{ Bangladesh } & \multicolumn{2}{|c|}{ India } & \multicolumn{2}{|c|}{ Pakistan } \\
\hline Variables & Coefficients & t- statistic & Coefficients & t- statistic & Coefficients & $\mathrm{t}$ - statistic \\
\hline Constant & -1.784 & -1.028 & -0.110 & -0.034 & 0.494 & $1.877^{*}$ \\
\hline CSFG & 0.266 & $2.804^{* * *}$ & 1.826 & $3.322^{* * *}$ & 0.052 & $3.358^{* * *}$ \\
\hline $\mathrm{AQ}$ & 0.626 & $3.233^{* * *}$ & -1.443 & $-1.824^{*}$ & 0.037 & $1.963^{* *}$ \\
\hline FS & 0.023 & 0.285 & 0.105 & 0.151 & -0.027 & $-2.207^{* *}$ \\
\hline LEV & 0.198 & 1.107 & -1.296 & $-2.405^{* *}$ & 0.047 & 0.918 \\
\hline PROF & 5.176 & 0.784 & -4.629 & $-1.953^{*}$ & -0.649 & $-4.411^{* * *}$ \\
\hline MTB & 0.111 & 0.942 & -0.085 & -1.484 & 0.030 & $1.755^{*}$ \\
\hline Adj R2 & \multicolumn{2}{|c|}{0.277} & \multicolumn{2}{|c|}{0.266} & \multicolumn{2}{|c|}{0.353} \\
\hline F-statistic & \multicolumn{2}{|c|}{$3.552^{* * *}$} & \multicolumn{2}{|c|}{$3.412^{* * *}$} & \multicolumn{2}{|c|}{$4.636^{* * *}$} \\
\hline $\mathrm{N}$ & \multicolumn{2}{|c|}{700} & \multicolumn{2}{|c|}{700} & \multicolumn{2}{|c|}{700} \\
\hline
\end{tabular}

***,*** $=$ statistically significant at less than $0.10,0.50$ and 0.01 
hypothesized i.e. CSFG has a positive significant effect on accounting conservatism.

Based on the Hausman specification test, the following table 5 shows the results of firm fixed effect model for equation $1 \mathrm{~B}$

Table 5: Results of Equation 1(B)

\begin{tabular}{|c|c|c|c|c|c|c|}
\hline & \multicolumn{2}{|c|}{ Bangladesh } & \multicolumn{2}{|c|}{ India } & \multicolumn{2}{|c|}{ Pakistan } \\
\hline Variables & Coefficients & t- statistic & Coefficients & t- statistic & Coefficients & $\mathrm{t}$ - statistic \\
\hline Constant & -2.118 & -1.224 & -0.205 & -0.064 & 0.452 & $1.721^{*}$ \\
\hline CSFG & 0.250 & $2.631^{* * *}$ & 2.005 & $3.61^{* * *}$ & 0.064 & $3.926^{* * *}$ \\
\hline$A Q$ & 0.495 & $2.465^{* *}$ & -1.342 & $-1.69^{*}$ & 0.224 & $2.698^{* * *}$ \\
\hline $\mathrm{CSFG}^{*} \mathrm{AQ}$ & 0.278 & $2.369^{* * *}$ & -0.305 & $-2.076^{* *}$ & -0.055 & $-2.306^{* *}$ \\
\hline FS & 0.038 & 0.477 & 0.120 & 0.174 & -0.027 & $-2.222^{* *}$ \\
\hline LEV & 0.171 & 0.958 & -1.321 & $-2.456^{* *}$ & 0.049 & 0.954 \\
\hline PROF & 5.955 & 0.906 & -4.420 & $-1.869^{*}$ & -0.664 & $-4.521^{* * *}$ \\
\hline MTB & 0.138 & 1.168 & -0.080 & -1.388 & 0.032 & $1.852^{*}$ \\
\hline Adj $R^{2}$ & \multicolumn{2}{|c|}{0.282} & \multicolumn{2}{|c|}{.270} & \multicolumn{2}{|c|}{0.282} \\
\hline F-statistic & \multicolumn{2}{|c|}{$3.598^{* * *}$} & \multicolumn{2}{|c|}{$3.442^{* * *}$} & \multicolumn{2}{|c|}{$3.598^{* * *}$} \\
\hline $\mathrm{N}$ & \multicolumn{2}{|c|}{700} & \multicolumn{2}{|c|}{700} & \multicolumn{2}{|c|}{700} \\
\hline
\end{tabular}

${ }^{*},{ }^{* *},{ }^{* *}=$ statistically significant at less than $0.10,0.50$ and 0.01

The results of the equations $1(\mathrm{~B})$ show that the interaction term $\mathrm{CSFG}^{*} \mathrm{AQ}$ is significant in above three estimations. The signs are also relevant to that was hypothesized i.e. AQ weakens the relationship between CSFG and AC.

Based on the Hausman specification test, the following table 6 shows the results of firm fixed effect model for equation $2 \mathrm{~A}$

The results show that CSFG is significant with signs relevant to that was hypothesized i.e. CSFG has a positive significant effect on accounting conservatism.

Based on the Hausman specification test, the following table 7 shows the results of firm fixed effect model for equation $2 \mathrm{~B}$

The results of the equations 2(B) show that the interaction term $\mathrm{CSFG}^{*} \mathrm{DQ}$ is significant in all three estimations. The signs are also relevant to that was hypothesized i.e. DQ weakens the relationship between CSFG and AC. 
Table 6: Results of Equation 2(A)

\begin{tabular}{|c|c|c|c|c|c|c|}
\hline & \multicolumn{2}{|c|}{ Bangladesh } & \multicolumn{2}{c|}{ India } & \multicolumn{2}{c|}{ Pakistan } \\
\hline Variables & Coefficients & t- statistic & Coefficients & t- statistic & Coefficients & t- statistic \\
\hline Constant & -3.154 & $-1.796^{*}$ & 1.920 & 0.579 & 0.204 & 0.7031 \\
\hline CSFG & 0.286 & $2.996^{* * *}$ & 1.894 & $3.446^{* * *}$ & 0.055 & $3.496^{* * *}$ \\
\hline DQ & -2.149 & $-2.175^{* *}$ & -5.251 & $-2.198^{* *}$ & -2.149 & $-2.175^{* *}$ \\
\hline FS & 0.131 & 1.541 & -0.017 & -0.024 & 0.131 & 1.541 \\
\hline LEV & 0.156 & 0.867 & -1.265 & $-2.357^{* *}$ & 0.156 & 0.867 \\
\hline PROF & 6.816 & 1.030 & -4.318 & $-1.82^{* *}$ & 6.816 & 1.030 \\
\hline MTB & 0.093 & 0.786 & -0.086 & -1.502 & 0.093 & 0.786 \\
\hline Adj R2 & \multicolumn{2}{|c|}{0.270} & \multicolumn{2}{c|}{0.270} & \multicolumn{2}{c|}{0.270} \\
\hline F-statistic & $3.464^{* * *}$ & \multicolumn{2}{c|}{$3.43^{* * *}$} & \multicolumn{2}{c|}{700} \\
\hline N & \multicolumn{2}{|c|}{700} & \multicolumn{3}{c|}{700} & \multicolumn{3}{c|}{} \\
\hline
\end{tabular}

${ }^{*}, * *, * * *$ statistically significant at less than $0.10,0.50$ and 0.01

Table 7: Results of Equation 2(B)

\begin{tabular}{|c|c|c|c|c|c|c|}
\hline & \multicolumn{2}{|c|}{ Bangladesh } & \multicolumn{2}{|c|}{ India } & \multicolumn{2}{|c|}{ Pakistan } \\
\hline Variables & Coefficients & t- statistic & Coefficients & t- statistic & Coefficients & t- statistic \\
\hline Constant & -3.445 & $-1.969^{* *}$ & 1.431 & 1.212 & -1.067 & $-2.306^{* *}$ \\
\hline CSFG & 0.290 & $3.057^{* * *}$ & 0.982 & $1.801^{*}$ & 0.400 & $4.027^{* * *}$ \\
\hline $\mathrm{DQ}$ & -2.263 & $-2.301^{* * *}$ & 1.431 & 1.067 & -1.067 & $-2.306^{* *}$ \\
\hline $\mathrm{CSFG}^{*} \mathrm{DQ}$ & 0.347 & $2.67^{* * *}$ & -5.041 & $-2.02^{* *}$ & 0.400 & $4.027^{* * *}$ \\
\hline FS & 0.143 & $1.691^{*}$ & 0.123 & 1.079 & 2.871 & $4.188^{* * *}$ \\
\hline LEV & 0.150 & 0.835 & -1.250 & $-3.061^{* * *}$ & -0.607 & $-3.521^{* * *}$ \\
\hline PROF & 7.042 & 1.071 & -2.621 & $-2.07^{* *}$ & -0.031 & $-2.602^{* * *}$ \\
\hline MTB & 0.091 & 0.791 & -0.012 & -0.366 & 0.033 & 0.646 \\
\hline Adj $R^{2}$ & \multicolumn{2}{|c|}{0.277} & \multicolumn{2}{|c|}{0.195} & \multicolumn{2}{|c|}{0.368} \\
\hline F-statistic & \multicolumn{2}{|c|}{$3.535^{* * *}$} & \multicolumn{2}{|c|}{$2.988^{* * * *}$} & \multicolumn{2}{|c|}{$4.847^{* * *}$} \\
\hline $\mathrm{N}$ & \multicolumn{2}{|c|}{700} & \multicolumn{2}{|c|}{700} & \multicolumn{2}{|c|}{700} \\
\hline
\end{tabular}

${ }^{*}, * *,{ }^{* * *}=$ statistically significant at less than $0.10,0.50$ and 0.01 
Based on the Hausman specification test, the following table 8 shows the results of firm fixed effect model for equation $3 \mathrm{~A}$

Table 8: Results of Equation 3(A)

\begin{tabular}{|c|c|c|c|c|c|c|}
\hline & \multicolumn{2}{|c|}{ Bangladesh } & \multicolumn{2}{c|}{ India } & \multicolumn{2}{c|}{ Pakistan } \\
\hline Variables & Coefficients & t- statistic & Coefficients & t- statistic & Coefficients & t- statistic \\
\hline Constant & -2.465 & -1.407 & 1.166 & 0.347 & 0.169 & 0.582 \\
\hline CSFG & 0.268 & $2.827^{* * *}$ & 1.851 & $3.364^{* * *}$ & 0.059 & $3.765^{* * *}$ \\
\hline AQ & 0.654 & $3.382^{* * *}$ & -0.564 & -1.322 & 0.036 & $1.910^{* *}$ \\
\hline DQ & -2.347 & $-2.391^{* *}$ & -2.449 & -0.769 & 0.588 & $2.550^{* * *}$ \\
\hline FS & 0.089 & 1.046 & 0.030 & 0.043 & -0.029 & $-2.414^{* *}$ \\
\hline LEV & 0.161 & 0.895 & -1.256 & $-2.431^{* *}$ & 0.043 & 0.846 \\
\hline PROF & 5.855 & 0.892 & -4.159 & $-1.759^{*}$ & -0.782 & $-5.03^{* * *}$ \\
\hline MTB & 0.096 & 0.814 & -0.085 & -1.49 & 0.031 & $1.795^{*}$ \\
\hline Adj R2 & \multicolumn{3}{|c|}{0.281} & \multicolumn{2}{c|}{0.272} & \multicolumn{2}{c|}{0.359} \\
\hline F-statistic & $3.600^{* * *}$ & \multicolumn{3}{c|}{700} & \multicolumn{2}{c|}{700} \\
\hline N & 700 & \multicolumn{3}{c|}{$731^{* * *}$} \\
\hline
\end{tabular}

${ }^{*},{ }^{* *},{ }^{* * *}=$ statistically significant at less than $0.10,0.50$ and 0.01

The results of all three countries in our sample show CSFG is significant with signs relevant to that was hypothesized i.e. CSFG has a positive significant effect on accounting conservatism.

Based on the Hausman specification test, the following table 9 shows the results of firm fixed effect model for equation $3 \mathrm{~B}$

The results show that both interaction terms $\mathrm{CSFG}^{*} \mathrm{AQ}$ and $\mathrm{CSFG}^{*} \mathrm{DQ}$ are significant in case of Bangladesh and Pakistan. Whereas in case of India the interaction term is only slightly significant with a probability of 0.114 . The signs are also relevant to that was hypothesized i.e. both AQ and DQ weakens the relationship between CSFG and AC.

The results of equations $1(\mathrm{~A}), 2(\mathrm{~A})$ and 3(A) report a significant coefficient of CSFG. We therefore, accept our first hypothesis that there exist a significant positive relationship between corporate governance and accounting conservatism in case of listed non-financial firms in Bangladesh, India and Pakistan.

The results of equations $1(\mathrm{~B})$ and $3(\mathrm{~B})$ report a negative significant coefficient of 
Table 9: Results of Equation 3(B)

\begin{tabular}{|c|c|c|c|c|c|c|}
\hline & \multicolumn{2}{|c|}{ Bangladesh } & \multicolumn{2}{|c|}{ India } & \multicolumn{2}{|c|}{ Pakistan } \\
\hline Variables & Coefficients & t- statistic & Coefficients & t- statistic & Coefficients & t- statistic \\
\hline Constant & -2.939 & $-1.668^{*}$ & 0.353 & 0.014 & -0.974 & $-2.080^{* *}$ \\
\hline CSFG & 0.258 & $2.741^{* * *}$ & 2.559 & $3.591^{* * *}$ & 0.374 & $3.122^{* * *}$ \\
\hline AQ & 0.560 & $2.795^{* * *}$ & -0.453 & -1.061 & 0.184 & $2.224^{* *}$ \\
\hline $\mathrm{CSFG}^{*} \mathrm{AQ}$ & 0.210 & $1.769^{*}$ & -0.792 & $-1.985^{* *}$ & -0.047 & $-1.988^{* *}$ \\
\hline DQ & -2.337 & $-2.390^{* *}$ & -1.848 & -0.560 & 2.585 & $3.694^{* * *}$ \\
\hline $\mathrm{CSFG}^{*} \mathrm{DQ}$ & 0.312 & $2.389^{* *}$ & -5.168 & -1.441 & -0.539 & $-3.061^{* * *}$ \\
\hline FS & 0.108 & 1.277 & 0.006 & 0.009 & -0.031 & $-2.562^{* *}$ \\
\hline LEV & 0.136 & 0.763 & -1.301 & $-2.422^{* *}$ & 0.035 & 0.691 \\
\hline PROF & 6.607 & 1.012 & -4.115 & $-1.733^{*}$ & -0.811 & $-5.252^{* * *}$ \\
\hline MTB & 0.117 & 0.995 & -0.079 & -1.382 & 0.032 & $1.921^{* *}$ \\
\hline Adj $R^{2}$ & \multicolumn{2}{|c|}{0.204} & \multicolumn{2}{|c|}{0.273} & \multicolumn{2}{|c|}{0.372} \\
\hline F-statistic & \multicolumn{2}{|c|}{$3.685^{* * *}$} & \multicolumn{2}{|c|}{$3.432^{* * *}$} & \multicolumn{2}{|c|}{$4.836^{\text {*** }}$} \\
\hline $\mathrm{N}$ & \multicolumn{2}{|c|}{700} & \multicolumn{2}{|c|}{700} & \multicolumn{2}{|c|}{700} \\
\hline
\end{tabular}

$* * * * * * *$ statistically significant at less than $0.10,0.50$ and 0.01

$\mathrm{CSFG}^{*} \mathrm{AQ}$ in case of all sample countries. We therefore, accept our second hypothesis that the high audit quality moderates the association between corporate governance of firms and accounting conservatism in case of listed firms in Bangladesh, India and Pakistan.

The results of equations 2(B) and 3(B) report a negative significant coefficient of $\mathrm{CSFG}^{*} \mathrm{DQ}$. We therefore, accept our third hypothesis that the high disclosure quality moderates the association between corporate governance of firms and accounting conservatism in case of listed firms in Bangladesh, India and Pakistan.

The results of this study fully support the findings of Abdullah (2006), Haniffa and Hudaib (2006) and Ahmed and Duellman (2007). These researchers while exploring the effect of various corporate governance mechanism conclude that effective corporate governance does have an impact on the level of conservatism employed by firms especially that are listed in developed economies. The reason that, in most of the cases the corporate governance is employed as a tool to mitigate information asymmetry that in turn reduces the agency conflicts by employing more conservative accounting estimates. However the results are not aligned with the findings of Laford and Roychowdhury (2008) and Hu, Tam and Tan (2010) who report inverse 
relationship by arguing that if the corporate governance is improved the managers' interest will be aligned with that of the firm's and the demand for conservatism will be reduced. The results of an unreported analysis, where in the corporate governance and disclosure quality were measured as binary variables, show similar results thus making our results robust.

\section{Conclusion and Recommendations}

This study focused on answering questions related to the link between corporate governance and accounting conservatism and the moderating role of audit quality as well as disclosure quality on this relationship in three emerging economies of South Asia. Using a sample of 300 non-financial companies from Bangladesh, India and Pakistan, we look into the stated relationship by developing composite measures of accounting conservatism and corporate governance. We find that corporate governance is associated with accounting conservatism in a positive manner and high audit quality and disclosure quality weakens this relationship.

Our findings are in line with agency theory perspective wherein the existence of complex governance structures demand conservatism. Our findings are also in line with the idea of significance of conservatism in contracting wherein the managers employ more conservatism as a contracting tool to reduce information asymmetry. Moreover some of the new attributes of corporate governance are also being added to the literature. The researchers should now also consider these new attributes while analyzing the impact of corporate governance practices on strategic decisions of the firms.

The regulatory bodies working in developing economies along with the policy makers can now develop new yet effective policies by specifically targeting factors that are found to be significant in reducing conservatism. Another important implication for the academia and researchers, who should use the methods employed in this study to gauge accounting conservatism, is that it is a promising method that offers a numeric sense to the extent of conservatism. The results of this study are also helpful for investors and fund managers as they can better evaluate a firm with respect to the level of conservatism employed by that firm before investing a significant amount of funds into the firm. This study is limited to non-financial companies and those firms whose data was available and also to three emerging economies of South Asia. One can replicate this study by taking into account the financial sectors of Bangladesh, India and Pakistan or specifically the banking industry in these economies. This study can also be extended to NEST, EAGLE and G8 economies. 


\section{References}

Abdullah, S. N. (2006). Board structure and ownership in Malaysia: The case of distressed listed companies. Corporate Governance, 6(5), 582-594.

Ahmed, A. S., \& Duellman, S. (2007). Accounting conservatism and board of director characteristics: An empirical analysis. Journal of Accounting and Economics, 43(2-3), 411-437.

Artiach, T. C., \& Clarkson, P. M. (2013). Conservatism, disclosure and the cost of equity capital. Australian Journal of Management, 39(2), 293-314.

Ball, R., \& Shivakumar, L. (2005). Earnings quality in UK private firms: Comparative loss recognition timeliness. Journal of Accounting and Economics, 39(1), 83-128.

Basu, S. (1997). The conservatism principle and the asymmetric timeliness of earnings. Journal of Accounting and Economics, 24(1), 3-37.

Basu, S., Hwang, L. S., \& Jan, C. L. (2001). Auditor conservatism and quarterly earnings. Working Paper, City University of Hong Kong.

Beatty, A., Weber, J., \& Yu, J. J. (2008). Conservatism and debt. Journal of Accounting $\mathcal{G}$ Economics, 45(2-3), 154-174.

Beekes, W., Pope, P., \& Young, S. (2004). The link between earnings timeliness, earnings conservatism and board composition: Evidence from the UK. Corporate Governance: An International Review, 12(1), 47-59.

Blair, M. (1995). Ownership and control: Rethinking corporate governance for the twenty-first century, Brookings Institution, Washington DC.

Bliss, J.H. (1924). Management through accounts. New York, NY: The Ronald Press Co.

Brown, S., \& Hillegeist, S. A. (2007). How disclosure quality affects the level of information asymmetry. Review of Accounting Studies, 12(2-3), 443-477.

Cheung, Y. L., Jiang, P., \& Tan, W. (2010). A transparency disclosure index measuring disclosures: Chinese listed companies. Journal of Accounting and Public Policy, 29(3), 259280.

Ching, C.P., Teh, B.H., San, O.T., \& Hoe, H.Y. (2015). The relationship among audit quality, earnings management, and financial performance of Malaysian public listed companies. International Journal of Economics $\mathcal{E}$ Management, 9(1), 211-229.

Chung, R., Firth, M., \& Kim, J. (2003). Auditor conservatism and reported earnings. Accounting Business Research, 33, 19-32.

Claessens, S., Fan, J. P., \& Lang, L.H. (2006). The benefits and costs of group affiliation: Evidence from East Asia. Emerging Markets Review, 7(1), 1-26.

Claessens, S., Djankov, S., Fan, J. P. H., \& Lang, L. H. P. (1999). Expropriation of minority shareholders: 
Evidence from East Asia. World Bank Policy Research Working Paper No. 2088

Dharwadkar, R., George, G., \& Brandes, P. (2000). Privatization in emerging economies: an agency theory perspective. The Academy of Management Review, 25(3), 650-669.

Donovan, J., Frankel, R. M., \& Martin, X. (2015). Accounting conservatism and creditor recovery rate. The Accounting Review, 90(6), 2267-2303.

Elshandidy, T., \& Hassanein, A. (2014). Do IFRS and board of directors' independence affect accounting conservatism?. Applied Financial Economics, 24(16), 1091-1102.

Francis, J.R., \& Wang, D. (2008). The joint effect of investor protection and big 4 audits on earnings quality around the world. Contemporary Accounting Research, 25(1), 157-191.

Francis, J. R., Maydew, E. L. \& Sparks, H. C. (1999). The role of Big 6 auditors in the credible reporting of accruals. Auditing: A Journal of Practice $\mathcal{E}$ Theory, 18(2), 17-34.

Givoly, D., \& Hayn, C. (2000). The changing time-series properties of earnings, cash flows and accruals: Has financial reporting become more conservative?. Journal of Accounting and Economics, 29(3), $287-320$.

Haniffa, R., \& Hudaib, M. (2006). Corporate governance structure and performance of Malaysian listed companies. Journal of Business Finance $\mathcal{E}$ Accounting, 33(7-8), 1034-1062.

Hu, H., Tam, O., \& Tan, M. (2010). Internal governance mechanisms and firm performance in China. Asia Pacific Journal of Management, 27(4), 727-749.

Jensen, M. C., \& Meckling, W. H. (1976). Theory of the firm: Managerial behavior, agency costs and ownership structure. Journal of Financial Economics, 3(4), 305-360.

Kang, H., Cheng, M., \& Gray, S.J. (2007). Corporate governance and board composition: Diversity and independence of Australian boards. Corporate Governance: An International Review 15(2), 194-207.

Karami, G., Hoseini, A., \& Hasani, A. (2010). Examining the relationship between firm's strategic system and conservatism in companies listed on Tehran stock exchange. Journal of Accounting Studies, 2 (7), 610-615.

Khan, A., Muttakin, M. B., \& Siddiqui, J. (2015). Audit fees, auditor choice and stakeholder influence: Evidence from a family-firm dominated economy. British Accounting Review, 47(3), 304-320.

Kim, B., \& Jung, K. (2007). The influence of tax costs on accounting conservatism. KAIST, Business School Working Paper Series Index.

Krishnan, G. V., \& Visvanathan, G. (2008). Does the SOX definition of an accounting expert matter? The association between audit committee directors' accounting expertise and accounting conservatism. Contemporary Accounting Research, 25(3), 827-857.

Krishnan, G. V., \& Visvanathan, G. (2009). Do auditors price audit committee's expertise? The case 
of accounting versus non accounting financial experts. Journal of Accounting, Auditing $\mathcal{E}$ Finance, 24(1), 115-129.

Kung, F., Cheng, L., \& James, K. (2010). Effects of corporate ownership structure on earnings conservatism. Asian Journal of Finance $\mathcal{E}$ Accounting, 2(1), 47-67.

Lafond, R., \& Watts, R. (2008). The information role of conservative financial statements. The Accounting Review, 83(2), 443-478.

Lara, J. M. G., Osma, B. G., \& Penalva, F. (2009). The economic determinants of conditional conservatism. Journal of Business Finance $\mathcal{E}$ Accounting, 36(3-4), 336-372.

Latif, K., Bhatti, A., \& Raheman, A. (2017). Earnings Quality: A Missing Link between Corporate Governance and Firm Value. Business $\mathcal{E}$ Economic Review, 9, 255-279.

Lennox, C. (2005). Audit quality and executive officers' affiliations with CPA firms. Journal of Accounting and Economics, 39(2), 201-231.

Luo, Y., \& Tung, R. L. (2007). International expansion of emerging market enterprises: A spring board perspective. Journal of International Business Studies, 38(4), 481-498.

Ming, T. C., \& Gee, C. S. (2008). The influence of ownership structure on the corporate performance of Malaysian public listed companies. ASEAN Economic Bulletin, 25(2), 195-208.

Mohammed, N. F., Ahmed, K., \& Ji, X. (2017). Accounting conservatism, corporate governance and political connections. Asian Review of Accounting, 25(2), 288-318.

Muttakin, M., B., Khan, A., \& Mihret, D. G. (2017) Business group affiliation, earnings management and audit quality: Evidence from Bangladesh. Managerial Auditing Journal, 32(4-5), 427-444.

Noravesh, I., \& Hosseini, A. (2008). Examination of relationship between disclosure quality (Reliability and timeliness) and earnings management. Journal of Evaluations of Accounting and Audit, 55, 117-144.

Persakis, A., \& Iatridis, G. (2016). Audit quality, investor protection and earnings management during the financial crisis of 2008: An international perspective. Journal of International Financial Markets, Institutions $\mathcal{E}$ Money, 41, 73-101.

Rahman, R. A., \& Ali, F. H. M. (2006). Board, audit committee, culture and earnings management: Malaysian evidence. Managerial Auditing Journal, 21(7), 783-804.

Rahimian, N. E., \& Ebrahimi, M. M. (2013). The relationship between disclosure quality and conservatism in Tehran Stock Exchange. Accounting Empirical Research, 5(5), 63-72.

Rajgopal, S., Srinivasan, S., \& Zheng, X. (2015). Measuring audit quality. Working paper.

Ren, Y. (2014). Corporate governance, conservatism and firm performance: Evidence from China. (Doctoral thesis). School of Business, Faculty of Business and Law, Edith Cowan University, Perth, Western Australia. 
Rosilda. (2009). The relationship between corporate governance and accounting conservatism. (Doctoral thesis). School of Accounting, Faculty of Business, University of New South Wales, Australia.

Roychowdhury, S., \& Watts, R. L. (2007). Asymmetric timeliness of earnings, market-to-book and conservatism in financial reporting. Journal of Accounting and Economics, 44(1-2), 2-31.

Sarkar, J., Sarkar, S., \& Sen, K. (2008). Board of directors and opportunistic earnings management: Evidence from India. Journal of Accounting, Auditing and Finance, 23(4), 517-551.

Shuto, A., \& Takada, T. (2010). Managerial ownership and accounting conservatism in Japan: A test of management entrenchment effect. Journal of Business Finance $\mathcal{E}$ Accounting, 37(778), 815-840.

Subramaniam, N. (2006). Agency theory and accounting research: An overview of some conceptual and empirical issues. In Z. Hoque (Ed.), Methodological Issues in Accounting Research: Theories and Methods (pp. 55-81). London, United Kingdom: Spiramus.

Suleiman, S., \& Anifowose, M. (2014). Corporate Governance and Conditional Accounting Conservatism in Nigeria Listed Food and Beverages Firms. International Journal of Accounting and Taxation, 2(2), 65-84.

Watts, R. L. (2003). Conservatism in accounting part I: Explanations and implications. Accounting horizons, 17(3), 207-221.

Watts, R. L., \& Zimmerman, J. L. (1986). Positive accounting theory. Prentice Hall, Englewood Cliffs, NJ.

Wei, G. (2007). Ownership structure, corporate governance and company performance in China. Asia Pacific Business Review, 13(4), 519-545.

Yatim, P., Kent, P., \& Clarkson, P. (2006). Governance structures, ethnicity, and audit fees of Malaysian listed firms. Managerial Auditing Journal, 21(7), 757-782.

Yunos, R. M., Smith, M., \& Ismail, Z. (2011). Accounting conservatism and ownership concentration: Evidence from Malaysia. Journal of Business and Policy Research, 5(2), 1-15.

Yunos, R. M. (2011). The effect of ownership concentration, board of directors, audit committee and ethnicity on conservative accounting: Malaysian evidence. (Doctoral thesis). School of Accounting, Finance and Economics Faculty of Business and Law Edith Cowan University, Perth Western Australia.

Young, M. N., Peng, M. W., Ahlstrom, D., Bruton, G. D., \& Jiang, Y. (2008). Corporate governance in emerging economies: A review of the principal-principal perspective. Journal of Management Studies, 45(1), 196-220.

Zhang, J. (2008). The contracting benefits of accounting conservatism to lenders and borrowers. Journal of Accounting $\mathcal{E}$ Economics, 45(1), 27-54. 
Appendix 1: Classification of Sample Firms

\begin{tabular}{|c|c|c|c|c|c|}
\hline \multicolumn{2}{|c|}{ Bangladesh } & \multicolumn{2}{|c|}{ India } & \multicolumn{2}{|c|}{ Pakistan } \\
\hline $\begin{array}{l}\text { Name of the } \\
\text { Industry }\end{array}$ & $\begin{array}{c}\text { No of sample } \\
\text { companies }\end{array}$ & $\begin{array}{l}\text { Name of the } \\
\text { Industry }\end{array}$ & $\begin{array}{c}\text { No of sample } \\
\text { companies }\end{array}$ & $\begin{array}{l}\text { Name of the } \\
\text { Industry }\end{array}$ & $\begin{array}{c}\text { No of sample } \\
\text { companies }\end{array}$ \\
\hline Cement & 5 & 2/3 Wheelers & 3 & $\begin{array}{l}\text { Automobile } \\
\text { assembler }\end{array}$ & 8 \\
\hline $\begin{array}{l}\text { Ceramics } \\
\text { Sector }\end{array}$ & 4 & Agrochemicals & 5 & $\begin{array}{l}\text { Automobile } \\
\text { parts and } \\
\text { Accessories } \\
\end{array}$ & 5 \\
\hline Engineering & 15 & Aluminium & 2 & $\begin{array}{c}\text { Cable and } \\
\text { electrical } \\
\text { goods }\end{array}$ & 4 \\
\hline Food \& Allied & 9 & $\begin{array}{c}\text { Auto Parts \& } \\
\text { Equipment }\end{array}$ & 2 & Cement & 11 \\
\hline Fuel \& Power & 12 & $\begin{array}{c}\text { Auto Tyres } \\
\& \text { Rubber } \\
\text { Products }\end{array}$ & 4 & Chemical & 11 \\
\hline IT Sector & 3 & $\begin{array}{l}\text { Broadcasting } \\
\& \text { Cable TV }\end{array}$ & 1 & Engineering & 5 \\
\hline Jute & 2 & $\begin{array}{c}\text { Cars \& Utility } \\
\text { Vehicles }\end{array}$ & 2 & Fertilizer & 2 \\
\hline Miscellaneous & 7 & $\begin{array}{c}\text { Cement \& } \\
\text { Cement } \\
\text { Products } \\
\end{array}$ & 7 & $\begin{array}{c}\text { Food and } \\
\text { personal care } \\
\text { products }\end{array}$ & 6 \\
\hline $\begin{array}{l}\text { Paper \& } \\
\text { Printing }\end{array}$ & 1 & $\begin{array}{c}\text { Cigarettes-To- } \\
\text { bacco Prod- } \\
\text { ucts }\end{array}$ & 1 & $\begin{array}{l}\text { Glass and } \\
\text { ceramics }\end{array}$ & 4 \\
\hline $\begin{array}{c}\text { Pharma- } \\
\text { ceuticals \& } \\
\text { Chemicals }\end{array}$ & 16 & $\begin{array}{c}\text { Commercial } \\
\text { Vehicles }\end{array}$ & 3 & Jute & 0 \\
\hline $\begin{array}{l}\text { Services \& } \\
\text { Real Estate }\end{array}$ & 3 & $\begin{array}{l}\text { Commodity } \\
\text { Chemicals }\end{array}$ & 2 & $\begin{array}{l}\text { Leather and } \\
\text { tanneries }\end{array}$ & 1 \\
\hline $\begin{array}{c}\text { Tannery } \\
\text { Industries }\end{array}$ & 3 & $\begin{array}{l}\text { Consumer } \\
\text { Electronics } \\
\end{array}$ & 2 & Media & 0 \\
\hline $\begin{array}{c}\text { Telecommuni- } \\
\text { cation }\end{array}$ & 2 & $\begin{array}{c}\text { Electric Util- } \\
\text { ities }\end{array}$ & 6 & Miscellaneous & 0 \\
\hline Textile & 18 & $\begin{array}{c}\text { Exploration \& } \\
\text { Production }\end{array}$ & 2 & $\begin{array}{l}\text { Oil and gas } \\
\text { exploration } \\
\text { companies }\end{array}$ & 1 \\
\hline
\end{tabular}




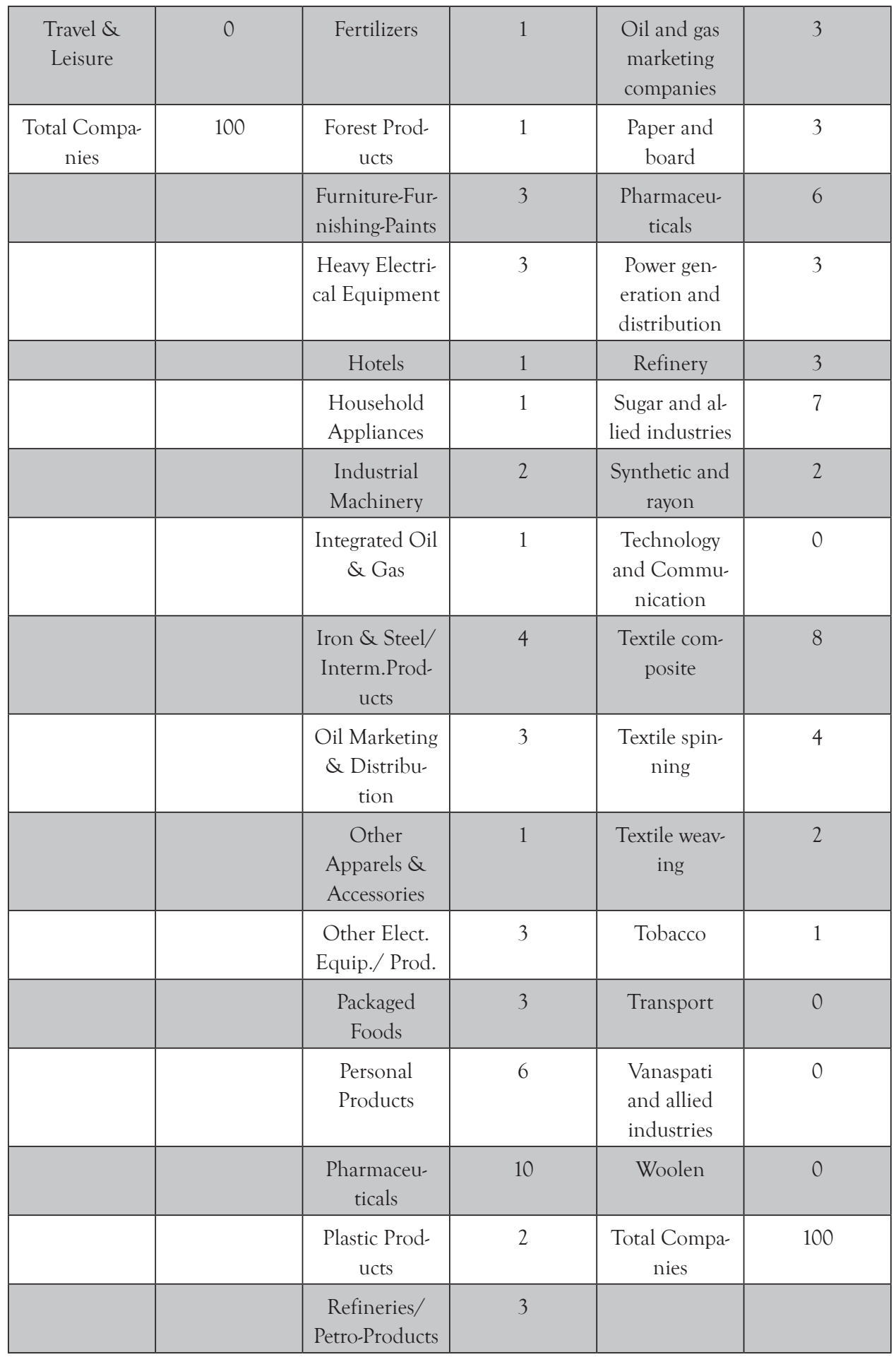




\begin{tabular}{|l|c|c|c|l|l|}
\hline & Sugar & 2 & & \\
\hline & & Tea \& Coffee & 1 & & \\
\hline & & $\begin{array}{c}\text { Telecom } \\
\text { Cables }\end{array}$ & 1 & & \\
\hline & & Textiles & 6 & & \\
\hline & & Total & 100 & & \\
\hline
\end{tabular}

Appendix 2: Disclosure Quality Index Measurement

\begin{tabular}{|c|c|c|}
\hline & Title & Score \\
\hline 1 & Corporate objectives & \\
\hline 1.1 & Mission & 1 \\
\hline 1.2 & Vision & 1 \\
\hline 1.3 & Overall strategic objectives & 1 \\
\hline 1.4 & Core Values & 1 \\
\hline 1.5 & Code of conduct/ethical principle/statement of ethics & 1 \\
\hline \multirow[t]{2}{*}{1.6} & History of the company/profile & 1 \\
\hline & Total & 6 \\
\hline 2 & Director's Report/chairman's/CEO overview & \\
\hline 2.1 & $\begin{array}{l}\text { Performance review of the company (for detailed disclosure more weight age } \\
\text { should be given) }\end{array}$ & 4 \\
\hline 2.2 & $\begin{array}{l}\text { Disclosing the Business risks and challenges that company is facing and steps } \\
\text { taken to mitigate such risks in future }\end{array}$ & 4 \\
\hline 2.3 & A general review of the future prospects, outlook and plans for expansion & 3 \\
\hline 2.4 & Business process reengineering/development activities & 1 \\
\hline 2.5 & $\begin{array}{l}\text { Disclosure of the contribution of the company to the national exchequer of } \\
\text { the country }\end{array}$ & 1 \\
\hline 2.6 & $\begin{array}{l}\text { Contribution towards the development of human capital i.e. work force plan- } \\
\text { ning, staff training etc }\end{array}$ & 2 \\
\hline 2.7 & How corporate social responsibilities, environmental issues been met & 2 \\
\hline 2.8 & Market share information & 1 \\
\hline 2.9 & $\begin{array}{l}\text { Disclosing how liquidity problems been solved and the company's plan to } \\
\text { manage its repayment of debts and recover losses }\end{array}$ & 2 \\
\hline 2.1 & Information regarding different segments and units of the company & 2 \\
\hline \multirow[t]{2}{*}{2.11} & Safety of the employees & 2 \\
\hline & Total & 24 \\
\hline
\end{tabular}




\begin{tabular}{|c|c|c|}
\hline 3 & Disclosure & \\
\hline 3.1 & Financial Reporting Results & 1 \\
\hline 3.2 & Accounting standards used for the accounts & 1 \\
\hline 3.3 & Comprehensive related party disclosure & 1 \\
\hline 3.4 & Disclosure of all changes in corresponding figures & 1 \\
\hline 3.5 & Adequate disclosure of significant judgment and estimates & 1 \\
\hline 3.6 & Detailed disclosure of Financial instruments & 1 \\
\hline 3.7 & Further disclosure of facilities provided to $\mathrm{CEO}$ and Directors & 1 \\
\hline 3.8 & Detailed disclosure of all contingencies and commitments & 1 \\
\hline 3.9 & Adequate disclosure of new accounting standard and their expected impact & 1 \\
\hline 3.1 & Detailed capacity disclosure & 1 \\
\hline 3.11 & Segmental analysis & 1 \\
\hline 3.12 & Cash flow statement based on direct method & 1 \\
\hline 3.13 & Disclosure of fair value of property, plant and equipment & 1 \\
\hline 3.14 & Adequate disclosure of change in accounting policy & 1 \\
\hline 3.15 & Expenditure on Research and development & 1 \\
\hline 3.16 & Information on Auditors & 1 \\
\hline 3.17 & Disclosure of how much is paid to Auditors for consulting and other work & 1 \\
\hline \multirow[t]{2}{*}{3.18} & Number of employees & 1 \\
\hline & Total & 18 \\
\hline \multirow[t]{2}{*}{4} & Stake holder's Information & \\
\hline & Information relevant for shareholders and other users of financial statements & \\
\hline 4.1 & Investor information for 6 years & 10 \\
\hline 1 & Gross profit ratio & 0.4 \\
\hline 2 & EBITDA Margin to sales & 0.4 \\
\hline 3 & Net profit to sales & 0.4 \\
\hline 4 & Return on equity & 0.4 \\
\hline 5 & Return on capital employed & 0.4 \\
\hline 6 & Weighted average cost of debt & 0.4 \\
\hline 7 & Inventory turnover ratio/No of days in inventory & 0.4 \\
\hline 8 & Debtor turnover ratio/ No of days in receivable & 0.4 \\
\hline 9 & Creditor turnover ratio/ No of days in payables & 0.4 \\
\hline 10 & Operating cycle & 0.4 \\
\hline 11 & Total assets turnover ratio/ Fixed assets turnover ratio & 0.4 \\
\hline
\end{tabular}




\begin{tabular}{|c|c|c|}
\hline 12 & Current ratio & 0.4 \\
\hline 13 & Quick / Acid test ratio & 0.4 \\
\hline 14 & Price earnings ratio & 0.4 \\
\hline 15 & Cash dividend per share & 0.4 \\
\hline 16 & Bonus shares issued & 0.4 \\
\hline 17 & Dividend yield ratio & 0.4 \\
\hline 18 & Dividend payout ratio & 0.4 \\
\hline 19 & Dividend cover ratio & 0.4 \\
\hline 20 & Debt: equity ratio & 0.4 \\
\hline 21 & Interest cover ratio & 0.4 \\
\hline 22 & $\begin{array}{l}\text { Breakup value per share without including the effect of surplus on revaluation } \\
\text { of fixed assets }\end{array}$ & 0.4 \\
\hline 23 & $\begin{array}{l}\text { Breakup value per share including the effect of surplus on revaluation of fixed } \\
\text { assets }\end{array}$ & 0.4 \\
\hline 24 & Market value per share at the end of the year & 0.4 \\
\hline \multirow[t]{2}{*}{25} & EBTIDA & 0.4 \\
\hline & Total & 10 \\
\hline \multirow[t]{2}{*}{4.2} & Summary of cash flow statements for six year & 1 \\
\hline & Shareholders information & \\
\hline 4.3 & Shares held by sponsors / directors/ executive & 1 \\
\hline 4.4 & $\begin{array}{l}\text { Vertical horizontal analysis of balance sheet and profit and loss account for } 6 \\
\text { years }\end{array}$ & 4 \\
\hline \multirow[t]{2}{*}{4.5} & $\begin{array}{l}\text { Statement of value added distributed to employees, government, shareholders, } \\
\text { creditors, society and business }\end{array}$ & 4 \\
\hline & Total & 20 \\
\hline 5 & Corporate Governance Disclosures & \\
\hline \multirow[t]{4}{*}{5.1} & Date of authorization of financial statements by the Board of directors & 10 \\
\hline & Within 45 days (10 marks) & \\
\hline & Within 60 days (7 marks) & \\
\hline & Within 75 days (4 marks) & \\
\hline 5.2 & $\begin{array}{c}\text { Statement of compliance with the best practice of code of corporate gover- } \\
\text { nance (No marks in case of other than clean review report) }\end{array}$ & 1 \\
\hline 5.3 & The board structure and its committees & 1 \\
\hline 5.4 & Chairman of the board other than CEO & 1 \\
\hline 5.5 & $\begin{array}{c}\text { Information on the Board committees and their terms of references and } \\
\text { number of meetings held }\end{array}$ & \\
\hline
\end{tabular}




\begin{tabular}{|c|c|c|}
\hline A & Information on the Board committees & \\
\hline B & Terms of references & \\
\hline C & Number of meetings held & \\
\hline 5.6 & Role and function of the board of directors & 2 \\
\hline 5.7 & Salient features of the audit committee charter/terms of reference & 1 \\
\hline 5.8 & Name of independent Directors /Non executive's directors to be disclosed & 1 \\
\hline 5.9 & Disclose for all members of board of directors & 2 \\
\hline A & Profile of each director & \\
\hline B & Cnvolvement /engagement of each director in their companies/entities as & \\
\hline 5.1 & Non executive directors on the audit committee (full marks if all are non- exec- & 2 \\
\hline 5.11 & utive directors, else zero) & 2 \\
\hline 5.12 & Name list of board attendance & 2 \\
\hline 5.13 & Training and development activities for directors & 1 \\
\hline 5.14 & Organizational chart & 1 \\
\hline 5.15 & Disclosure of criteria to evaluate Board performance & 1 \\
\hline 5.16 & CEO performance review & 1 \\
\hline & Event Calendar & Total \\
\hline & Grand Total & 1 \\
\hline
\end{tabular}

